\title{
Designing Business Models through a Combination of BMC and UML Methods at Eiger Adventure Store Bandung
}

\author{
Perancangan Model Bisnis Melalui Kombinasi Metode BMC dan UML \\ di Eiger Adventure Store Bandung
}

Received:

17 December 2019

Accepted:

22 June 2020

Published:

19 August 2020

\author{
${ }^{*}$ Muhammad Fadel Diva, ${ }^{2}$ Yudi Priyadi \\ ${ }^{1,2}$ Manajemen Bisnis Telekomunikasi dan Informatika, \\ FEB, Universitas Telkom \\ Bandung, Indonesia \\ E-mail: ${ }^{1}$ fadeldiva@student.telkomuniversity.ac.id, \\ 2whyphi@telkomuniversity.ac.id \\ *Corresponding Author
}

\begin{abstract}
Eiger Adventure Store Bandung is a company that manufactures outdoor clothing and accessories. The problem with Eiger, related to the lack of activities to educate customers about the difference between original and counterfeit products. Referring to the problems in Eiger, the purpose of this study is to design a Business Model Canvas (BMC), design a business model using the Unified Model Language (UML), create a User Interface visualization through a MockupMockup. The research method used is qualitative through SWOT support. Referring to the BMC of this research, a new business model recommendation has been produced, namely QR Code Scan. This business model has been described through UML and is visualized with Mock-Up. The UML diagram involved, among them, is the Use Case Diagram, which consists of five actors, namely customers, employees, cashiers, admins, and warehouse employees. The actor interacts on four Use Cases, namely choosing a product, QR Code Scan, Database, and payment. The Class Diagram consists of five main classes: customers, employees, cashiers, admins, and warehouse employees. The process contained in the QR Code Scan is a solution to provide education to customers to be able to distinguish genuine or imitation products.
\end{abstract}

Keyword-Business Model Canvas, Unified Model Language, QR Code Scan, SWOT

Abstrak-Eiger Adventure Store Bandung adalah suatu perusahaan yang memproduksi pakaian dan aksesoris outdoor. Permasalahan pada Eiger, berkaitan dengan kurangnya kegiatan mengedukasi para pelanggan, mengenai perbedaan produk asli dan produk tiruan. Merujuk permasalah pada Eiger tersebut, maka tujuan penelitian ini adalah membuat desain Business Model Canvas (BMC), merancang model bisnis menggunakan Unified Model Language (UML), membuat visualisasi User Interface melalui suatu Mock Up. Metode penelitian yang digunakan bersifat kualitatif melalui dukungan SWOT. Merujuk pada BMC penelitian ini, maka telah dihasilkan suatu rekomendasi model bisnis yang baru, yaitu QR Code Scan. Model bisnis ini telah digambarkan melalui UML, dan divisualiasikan dengan Mock Up. Diagram UML yang terlibat, diantaranya adalah Use Case Diagram yang terdiri dari lima aktor, yaitu pelanggan, pegawai, kasir, admin, dan pegawai gudang. Aktor tersebut berinteraksi pada empat Use Case, yaitu memilih produk, QR Code Scan, Database, dan pembayaran. Pada Class Diagram, terdiri dari lima kelas utama, yaitu: pelanggan, pegawai, kasir, admin, dan pegawai gudang. Proses yang terdapat pada QR Code Scan, merupakan solusi untuk memberikan edukasi kepada pelanggan, agar dapat membedakan produk asli atau tiruan.

Kata Kunci-Business Model Canvas, Unified Model Language, QR Code Scan, SWOT

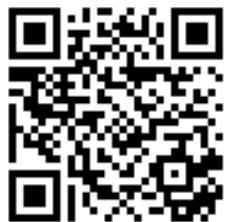




\section{INTRODUCTION}

Referring to the Creative Economic Agency[1], there are culinary and fashion businesses in the creative industry's sub-sector. It consists of 16 sub-sectors; culinary, fashion, craft, television \& radio, publishing, application \& game developers, advertising, music, photography, performing arts, product design, architecture, interior design, film, visual communication design. Indonesia has a high potential in this field because it has abundant resources, thus supporting its development. Indonesia has considerable human resources for the development of the creative economy. It is supported by a young population of around 43\%[2].

As one of the cities in West Java, Bandung is famous for its many fashion industries and has succeeded in developing it. It can be seen from the increasing growth of factory outlets, clothing companies, and distribution stores so that fashion becomes an icon of Bandung [3]. In Bandung, many fashion products can be found; one of them is clothing and outdoor accessories. The serene city of Bandung is one of the reasons why outdoor clothing products are trendy. Many companies produce outdoor clothing and accessories such as Consina, Rei, and Eiger.

Eiger Adventure Store Bandung is one of the companies that produce outdoor clothing and accessories. Ronny Lukito founded the company in 1979 in Bandung, West Java. At the beginning of the company, the company only had two sewing machines. Eiger customers have a high buying interest because they are interested in good product quality; this positive trend makes Eiger a quality brand and is a well-known brand in Indonesia to foreign countries.

However, Eiger Adventure Store Bandung's sales turnover decreased from year to year due to the counterfeiting of Eiger products that destroyed the product's image and the company. The lack of direction in educating customers about good product authenticity makes Eiger experience difficulties regarding counterfeiting of commodities in circulation. There are still many customers who cannot distinguish genuine Eiger products from imitation products.

The hypothesis for this research lies in the phenomenon of lack of education to customers to distinguish genuine products from counterfeit products in the customer relationship block in the business model canvas. Business model canvas (BMC) is a language that describes the visualization, assessment, and change of business models. This business model canvas has nine building blocks, namely: customer segments, value propositions, channels, customer relationships, revenue streams, vital resources, key activities, key partnerships, and cost structure[4].

The business model framework of this business model canvas is known to be better and easier to understand. Business model canvas is the best choice because it has proven its success and has been widely applied in domestic and foreign companies in making plans through the linkages of 
INTENSIF Vol.4 No.2 August 2020

ISSN: 2580-409X (Print) / 2549-6824 (Online)

DOI: https://doi.org/10.29407/intensif.v4i2.14097

nine blocks in the business model[5]. BMC creates general knowledge and language that can be shared because it is easy to interpret [6].

Eiger's problem is related to the lack of education to customers about the difference between original and counterfeit products. This education is essential for Eiger so that customers can know and buy wisely. However, Eiger still lacks a clear explanation. Eiger still has shortcomings in its business model, and it also needs to change its business model in Eiger. Based on the phenomena and problems that occur at Eiger Adventure Store Bandung, a methodology is required to design a system in the customer relationship block based on recommendations from the business model canvas. Two methods can be used in creating a system, namely structured and object-oriented methodology.

Unified Model Language is a visual language for determining, creating, and documenting artefacts from a system through models and diagrams, and offers an excellent framework [7]. UML is the specification most often used by the Object Management Group and is a standard tool for object-oriented modelling and documentation[8]. UML was chosen as a model for designing a system in the customer relationship block. UML is an option because it is very flexible, allowing various types of modelling, such as business model modelling workflows and event sequences. UML is becoming the standard for modelling software. This model provides blueprints for developers to know what is needed to build[9]. UML also facilitates comprehensive modelling techniques to describe system models and are used for various applications, especially for documentation purposes[10]. UML is used to capture and document all program requirements in object-based systems [11]. A series of UML diagrams that can do business model descriptions are presented in five charts, namely: Use Case Diagrams, Use Case Scenarios, Activity Diagrams, Sequence Diagrams, and Class Diagrams[12].

Based on this background, the research objectives achieved in this activity are making the Eiger Adventure Store Business Model Canvas design going on, making business model recommendations, and designing business models using the Unified Model Language based on the Business Model Canvas. Then as a visualization for the user interface, a mockup was made to the recommendations of the Eiger business model.

Based on Table 1, there are several summaries compared with the relevance of this research, namely: regarding differences in research variables, Unified Modeling Language, Business Model Canvas, application of business models, and implementation of a claim.

Table 1. COMPARISON TABLE PREVIOUS RESEARCH 
INTENSIF, Vol.4 No.2 August 2020

ISSN: 2580-409X (Print) / 2549-6824 (Online)

DOI: https://doi.org/10.29407/intensif.v4i2.14097

\begin{tabular}{|c|c|c|c|}
\hline Researcher & Tittle & $\begin{array}{l}\text { Resume } \\
\end{array}$ & Comparison \\
\hline $\begin{array}{l}\text { Abdeldjebbar, } \\
\text { B., \& } \\
\text { Azeddine, B }\end{array}$ & $\begin{array}{l}\text { Generating } \\
\text { Interface Prototype } \\
\text { for EnergyPlus IDD } \\
\text { file using Unified } \\
\text { Modeling Language } \\
\text { and Coloured Petri- } \\
\text { nets (2012) }\end{array}$ & $\begin{array}{l}\text { This paper proposes an approach to } \\
\text { making IDD interface prototypes from } \\
\text { scenarios. The scenario is obtained as a } \\
\text { sequence diagram according to UML } \\
\text { notation and is enriched with user } \\
\text { interface information. }\end{array}$ & $\begin{array}{l}\text { Having a different } \\
\text { discussion of } \\
\text { variables and } \\
\text { different research } \\
\text { objects. }\end{array}$ \\
\hline $\begin{array}{l}\text { Uke, S., \& } \\
\text { Thool, R. }\end{array}$ & $\begin{array}{l}\text { UML Based } \\
\text { Modeling for Data } \\
\text { Aggregation in } \\
\text { Secured Wireless } \\
\text { Sensor Network } \\
\text { (2016) }\end{array}$ & $\begin{array}{l}\text { In general, the design and development } \\
\text { of systems are done with the UML } \\
\text { approach. Then, show the use of UML } \\
\text { diagrams for data aggregation, from } \\
\text { sensing data with sensor nodes, } \\
\text { sending it to the cluster head for } \\
\text { gathering. }\end{array}$ & $\begin{array}{l}\text { Different research } \\
\text { objects }\end{array}$ \\
\hline $\begin{array}{l}\text { Rundupadang, } \\
\text { R., \& Priyadi, } \\
\text { Y. }\end{array}$ & $\begin{array}{l}\text { UML Design as a } \\
\text { Business Process } \\
\text { Recommendation } \\
\text { Based on BMC at } \\
\text { Geoff Max } \\
\text { Bandung (2018) } \\
\end{array}$ & $\begin{array}{l}\text { Based on the study results, researchers } \\
\text { provide recommendations in the } \\
\text { Business Model Canvas to strengthen } \\
\text { the Geoff Max Bandung business } \\
\text { model and design new business models } \\
\text { using the Unified Modeling Language. }\end{array}$ & $\begin{array}{l}\text { Different methods of } \\
\text { validity and research } \\
\text { objects }\end{array}$ \\
\hline $\begin{array}{l}\text { R. Sukmawati } \\
\& \text { Y. Priyadi }\end{array}$ & $\begin{array}{l}\text { Business Model } \\
\text { Design Using UML } \\
\text { Based on Fit / Gap } \\
\text { Analysis in Odoo } \\
\text { Inventory Module } \\
(2019) \\
\end{array}$ & $\begin{array}{l}\text { This study uses the Fit / Gap analysis } \\
\text { used to compare whether the system is } \\
\text { in line with company expectations, } \\
\text { then proceed with the Failure Mode } \\
\text { Effect Analysis (FMEA) to obtain a } \\
\text { Risk Priority Number (RPN) level. }\end{array}$ & $\begin{array}{l}\text { The process of } \\
\text { implementing UML } \\
\text { and different } \\
\text { research objects }\end{array}$ \\
\hline $\begin{array}{l}\text { Y. Priyadi \& } \\
\text { A. Prasetio }\end{array}$ & $\begin{array}{l}\text { Implementation of } \\
\text { Supply Chain } \\
\text { Business } \\
\text { Application through } \\
\text { Business Model } \\
\text { Canvas and } \\
\text { Waterfall } \\
\text { Framework } \\
\text { Collaborations for } \\
\text { Fish Farmers SMEs } \\
\text { in Ulekan Market } \\
\text { Bandung (2017) } \\
\end{array}$ & $\begin{array}{l}\text { This research resulted in the } \\
\text { development of e-SCM applications in } \\
\text { small groups of fish farmers based on } \\
\text { Open Source technology at the Ulekan } \\
\text { Market in Bandung, by collaborating } \\
\text { on the form of e-SCM and Data } \\
\text { Management. Then proceed with the } \\
\text { implementation of the supply chain } \\
\text { business through the collaboration of } \\
\text { the Business Model Canvas and } \\
\text { Waterfall Framework. }\end{array}$ & $\begin{array}{l}\text { Open-source } \\
\text { implementation for } \\
\text { BMC and different } \\
\text { research objects }\end{array}$ \\
\hline
\end{tabular}

\section{RESEARCH METHOD}

For the relationship between the concepts used and the stages of activities carried out in this study, a framework for thinking in completing research was made. This framework of thought can be seen in Figure 1. 
INTENSIF Vol.4 No.2 August 2020

ISSN: 2580-409X (Print) / 2549-6824 (Online)

DOI: https://doi.org/10.29407/intensif.v4i2.14097

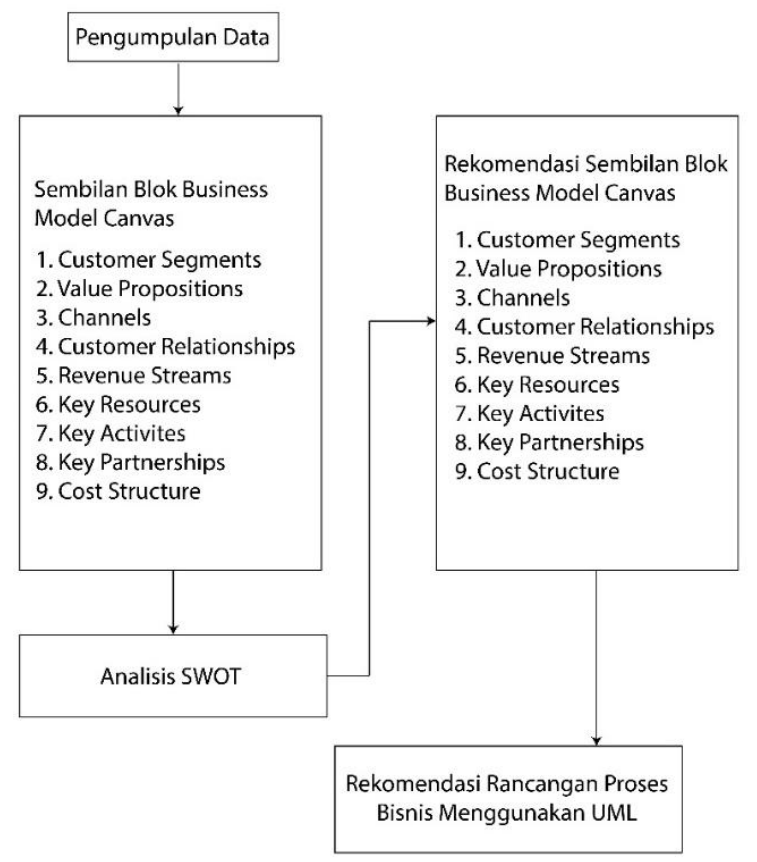

Figure 1. CONCEPTUAL FRAMEWORK

Based on Figure 1, in this section, the narrative framework is explained, namely:

1. Data collection. This step collects data in which there are ways in this research: the study of literature, observation, and interviews.

2. Nine Block Business Model Canvas That Happens. This step creates a business model canvas that is happening from the data that has been collected. It should be done as a basis for comparison to improve the business model that will be designed in the next steps.

3. SWOT analysis. This step carries out a SWOT analysis on the canvas business model that is happening to provide business model recommendations. Through this SWOT matrix analysis activity, it can be known about the weaknesses that are present in the business model that is happening, especially regarding activities related to Eiger in providing an education of its products.

4. Recommended Nine Block Business Model Canvas. This step makes recommendations for a new business model canvas, based on the SWOT analysis matrix. We will examine the linkages of nine BMC blocks regarding the advantages and disadvantages of Eiger activities related to product authenticity through this matrix.

5. Business Model Design Using the Unified Modeling Language. This step designs business models using a unified modeling language on five diagrams, namely: Use Case, Use Case Scenario, Activity Diagram, Sequence Diagram, and Class Diagram. 
The following presents a methodological stage, which describes all the activities carried out in the research. This methodology is based on the research framework contained in Figure 1. The methodology stages of the research activity are made to realize the structure that has been designed in the design of business models. The research steps can be seen in Figure 2.

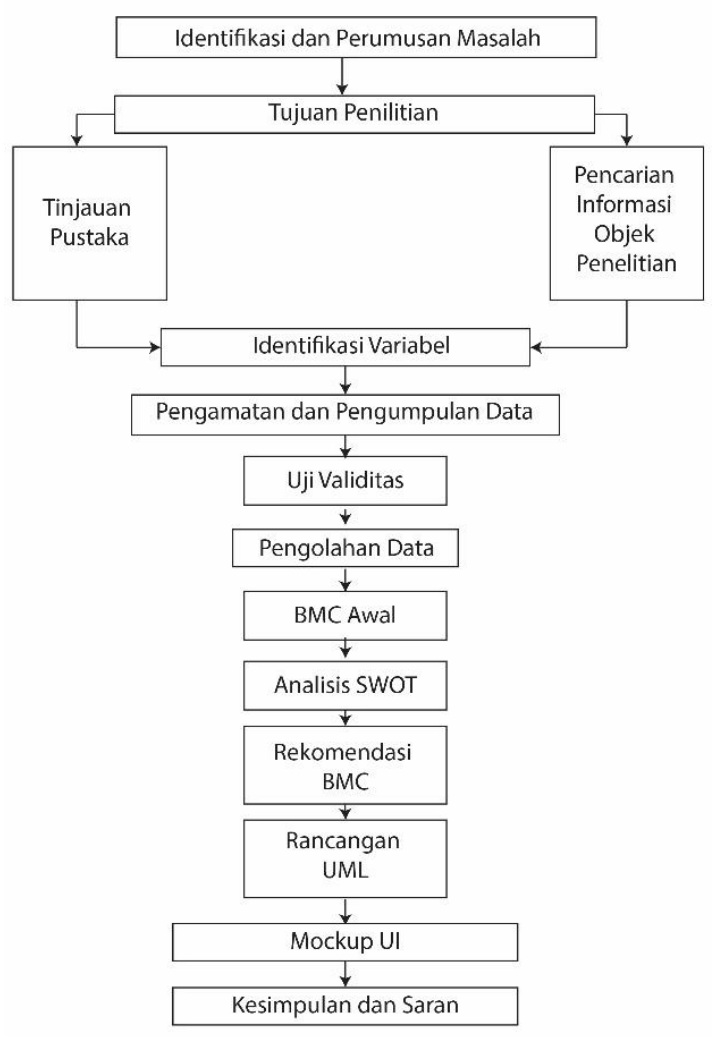

Figure 2. RESEARCH METHODOLOGY

Based on Figure 2, the steps in the figure were adapted from SDLC. SDLC has four stages, namely, planning, analysis, design, and implementation [13]. This section explained the narrative steps of research, starting from planning, analysis, design, and implementation. Explanations regarding these images can be seen as follows:

1. Planning

This stage begins with identifying and formulating the problem. In this stage, a search is made about the problem to be studied and creates a problem statement. After identifying, the research objectives will continue. Then do a literature review and search for information on research objects. There is information gathering activity about the problem under study, and also, the purpose of the research is Eiger Adventure Store Bandung. For the identification activities of this research, the variable is the business model canvas and unified modeling language. 
INTENSIF Vol.4 No.2 August 2020

ISSN: 2580-409X (Print) / 2549-6824 (Online)

DOI: https://doi.org/10.29407/intensif.v4i2.14097

2. Analysis

This stage starts with observation and data collection. Data collection is done through structured interview and observation methods. After the data is obtained, the validity test is carried out. There are four data validity tests in this study. These are credibility test, transferability test, dependability test, and confirmability test. Then do data processing or data analysis. In the data processing stage, there are three activities, namely: data reduction, data display, and conclusion drawing. Then we get the canvas business model that is happening or the initial BMC. In order to find out the relationship between the results of observations and data collection regarding the weaknesses of this system. It is concluded by conducting a SWOT analysis, the results of which will be used as a reference for the design stage.

3. Design

This stage starts from making a recommendation for a business model canvas; in this stage, a proposal for a business model is obtained, namely a QR code scan. The modeling rules contained in the unified modeling language are used to design the modeling of business processes. This design activity uses five diagrams, namely: use case diagrams, use case scenarios, activity diagrams, sequence diagrams, and class diagrams.

4. Implementation

This stage begins through the application of the UML design by creating a mockup user interface. Mockups are made using MarvelApp. Then proceed with giving conclusions and suggestions.

\section{RESULT AND DISCUSSION}

\section{A. Existing System}

\section{Business Model Canvas}

Based on the interview results, we get a business model that is happening at Eiger Adventure Store Bandung. Information and knowledge from the business model are mapped on a business model canvas with nine blocks to produce the overall experience as a basis for further processing[14][15]. The following is an illustration of the Eiger Adventure Store Bandung canvas business model, which can be seen in Figure 3. 
INTENSIF, Vol.4 No.2 August 2020

ISSN: 2580-409X (Print) / 2549-6824 (Online)

DOI: https://doi.org/10.29407/intensif.v4i2.14097

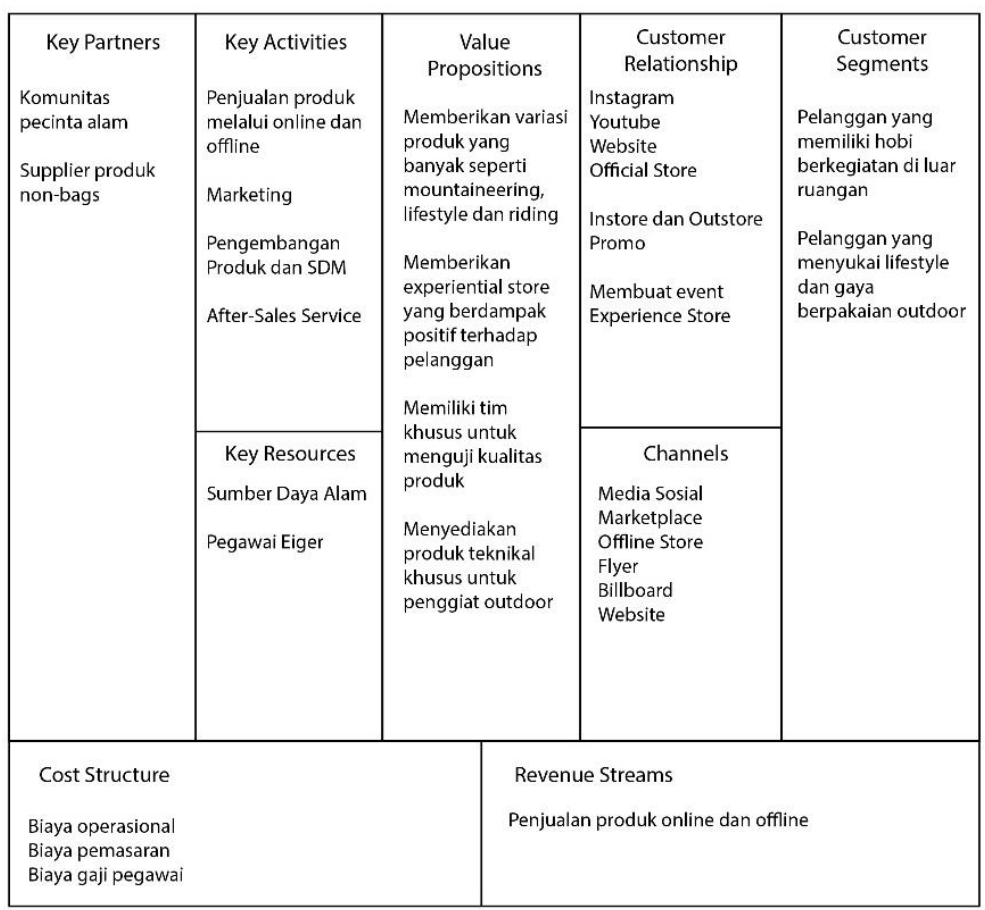

Figure 3. Business MOdELS ARE GOING ON

The following is a description of the business model canvas ninth block Eiger Adventure Store Bandung, namely:

a. Key Partnership

Eiger Adventure Store Bandung has two main partners, namely: a community of nature lovers and suppliers of non-bags products. The nature-loving community assists Eiger in running events every month, while suppliers of non-bags products help Eiger to provide materials in producing non-bags products.

b. Key Activities

Eiger Adventure Store Bandung's main activity is selling online and offline. Besides, Eiger develops products and human resources. Eiger has an after-sales service division, to provide guarantees for certain products and routinely carry out promotions.

c. Key Resources

Eiger Adventure Store Bandung has the primary resources, namely: natural resources and Eiger employees.

d. Cost Structure

The cost structure at Eiger is divided into three, namely: store operating costs, marketing costs, and employee salary costs. Store operating costs and employee salary costs are the highest costs at Eiger. 
INTENSIF Vol.4 No.2 August 2020

ISSN: 2580-409X (Print) / 2549-6824 (Online)

DOI: https://doi.org/10.29407/intensif.v4i2.14097

e. Customer Segment

Eiger Adventure Store Bandung has customer segments in the form of natural activists such as mountaineering, riding activists, lifestyle customers, and outdoor clothing.

f. Customer Relationship

Eiger deals with customers through social media, namely: Instagram-Youtube, through stores that embrace the experience store, and through the website. Eiger also often provides instore and out store promos, as well as creating events every month to communicate with customers.

g. Value Proposition

Eiger Adventure Store Bandung has three product lines, namely: mountaineering, lifestyle, and riding. The value offered by Eiger to customers, which in addition to preserving nature, also meets customer needs for mounting such as producing special tools. Eiger also adheres to experiential stores, to provide experiences that cannot be obtained when shopping online.

h. Channel

Eiger Adventure Store Bandung uses channels through official stores, marketplaces, websites, and social media. Eiger reaches its customers by flyering and advertising on billboards.

i. Revenue Stream

Eiger's leading source of income is in offline and online product sales.

\section{SWOT Analysis}

SWOT Analysis is an evaluation of the company's overall strengths, weaknesses, opportunities, and threats. This analysis is a way to monitor the external and internal marketing environment. The SWOT analysis can proceed to the formulation of objectives, develop specific goals for the planning period. Objectives are particular objectives concerning magnitude and time[16]. SWOT analysis is also a tool used for strategic planning and strategic management in organizations. It can be used effectively to build organizational strategies and competitive strategies[17]. A SWOT analysis is then performed to provide recommendations for improving the business model canvas based on the current business model canvas. SWOT analysis is needed to innovate new business models; this SWOT analysis is an integral part of designing a new business model that will later be applied. For a description of the results of the study of Strength, Weakness, Opportunities, and Threat at Eiger Adventure Store Bandung, can be seen in Figure 4. 
INTENSIF, Vol.4 No.2 August 2020

ISSN: 2580-409X (Print) / 2549-6824 (Online)

DOI: https://doi.org/10.29407/intensif.v4i2.14097

\begin{tabular}{|c|c|}
\hline $\begin{array}{l}\text { Strength } \\
\text { Kualitas produk yang baik } \\
\text { Penggunaan media promosi yang tepat } \\
\text { Garansi satu tahun pada produk tertentu } \\
\text { Pengembangan produk yang baik }\end{array}$ & $\begin{array}{l}\text { Weakness } \\
\text { Kurangnya edukasi produk terhadap } \\
\text { pelanggan untuk membedakan produk asli } \\
\text { dan produk palsu } \\
\text { Hanya memiliki satu sumber pendapatan }\end{array}$ \\
\hline $\begin{array}{l}\text { Opportunities } \\
\text { Franchise }\end{array}$ & $\begin{array}{l}\text { Threat } \\
\text { Pemalsuan produk eiger oleh pihak yang } \\
\text { tidak bertanggungjawab }\end{array}$ \\
\hline
\end{tabular}

Figure 4. ANALYsis Of Swot EIgER AdVENTURE StORE BANDUNG

Here, a description of a SWOT analysis of the Eiger Adventure Store Bandung, namely: a. Strength

Strength is something that becomes the strength of an organization, coming from the internal company. Power owned by Eiger Adventure Store Bandung is good product quality. The use of appropriate promotional media has a guarantee on certain products for one year and has quality product development.

b. Weakness

Weakness is a matter of the shortcomings of an organization that comes from within the company. From the phenomenon and interview results, it is found that the gap of Eiger Adventure Store Bandung is the lack of handling of counterfeiting products. Besides, Eiger has only one source of income from product sales. If the product is not sold, Eiger will experience a loss because it has no other income source.

c. Opportunities

Opportunities are opportunities for an organization that comes from an external company. Opportunities owned by Eiger Adventure Store Bandung can do a franchise on those who want to open an Eiger store in their area if all the requirements have been met.

d. Threat

Threats are things that threaten an organization, which comes from an external company. Risks owned by Eiger Adventure Store Bandung, namely its products, are falsified by irresponsible parties. 
INTENSIF Vol.4 No.2 August 2020

ISSN: 2580-409X (Print) / 2549-6824 (Online)

DOI: https://doi.org/10.29407/intensif.v4i2.14097

\section{Activity Diagram}

Presentation of business models that are happening at Eiger Adventure Store Bandung using the activity diagram. Activity diagrams are used in various domains to represent workflows [18]. In this diagram, there are three actors, namely customers, employees, and cashiers. This business model starts with the customer entering the store; then, the employee offers help finding the product they want. The customer will choose to accept advice or reject help, then select the product. After getting the desired outcome, the customer asks the product stock to the employee. Then the employee checks the product stock; if the product is not available, then the customer will choose the product again while if the product is available, the customer will make a payment at the cashier. The cashier will then ask the customer payment method; the customer chooses the payment method using cash or non-cash. The cashier will do the checkout after the customer selects the payment method, then submit the receipt and product to the customer. Then the customer receives the revenue and the product, then leaves the store. As a reference for this business model, it can be seen in Figure 5.

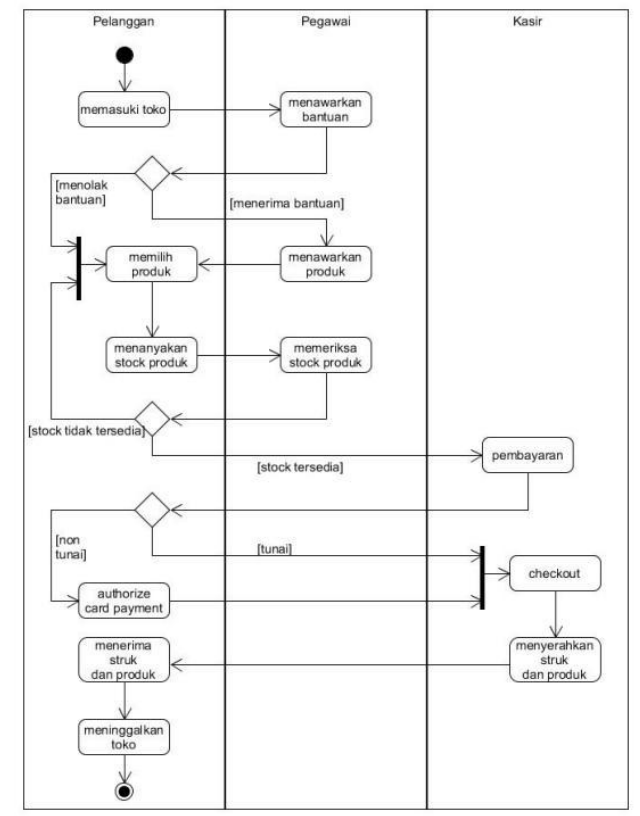

Figure 5. ACTIVITY DIAGRAM ON BUSINESS MODELS HAPPENING

\section{B. Business Model Recommendations}

\section{Recommendations for Improving Business Model Canvas}

There are business model recommendations on the canvas business model that is happening. The business model is in the customer relationship block. In this block, there are $\mathrm{QR}$ code scan recommendations. These recommendations need to be given to 
educating customers to know the original product. The way it works is by scanning the QR code on the product tag through the Eiger application; if the product is genuine, then product information will be displayed. For recommendations on this business model, it can be seen in the shaded section of the business model canvas block in Figure 6 .

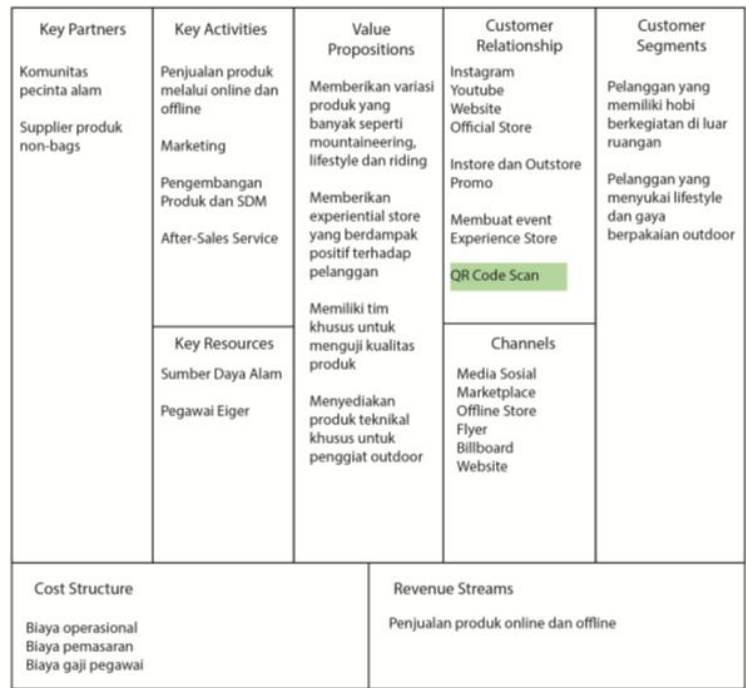

Figure 6. CANVAS MODEL BUSINESS RECOMMENDATIONS

\section{Recommended Business Models Using UML}

UML is a good description of making business model recommendations. UML provides a general vocabulary for object-based terms and diagram techniques to model every system development project from analysis to design[13]. UML used in this discussion consists of five diagrams, namely, use case diagrams, use case scenarios, activity diagrams, sequence diagrams, and class diagrams.

\section{a. Use Case Diagram $\mathrm{QR}$ code scan}

Use case diagrams explain how the system is used; the analysis must begin with the use case diagram and then proceed to the next stage. Use case diagrams to briefly describe or explain the actors who use the system and what they do[19]. This diagram explained the interaction between actors with the processes that occur in the order [20]. The following is a use case diagram for Eiger Adventure Store Bandung. The use case diagram consists of five actors, namely customer, employee, cashier, admin, and warehouse employee. The use case diagram also has four use cases, namely selecting products, QR code scan, database, and payment. 
INTENSIF Vol.4 No.2 August 2020

ISSN: 2580-409X (Print) / 2549-6824 (Online)

DOI: https://doi.org/10.29407/intensif.v4i2.14097

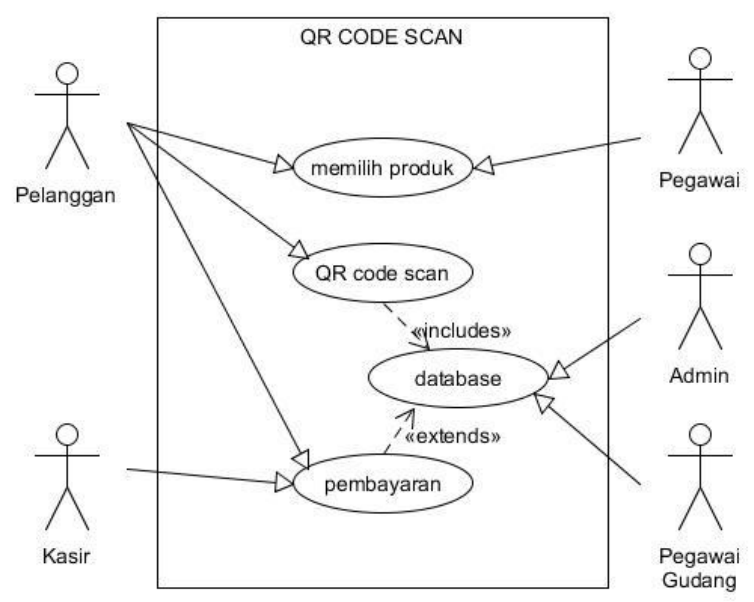

Figure 7. USE CASE EIGER AdVENTURE STORE BANDUNG DiAgRAM

b. Use Case Scenario, Activity Diagram, and Sequence Diagram QR code scan

Use case scenario is a step derived from the use case diagram; the scenario here explains the verbal articulation of the use case diagram. After using the use case scenario, then an activity diagram is needed to illustrate the overall flow of activities related to the system. Then a sequence diagram is needed to show the sequence of activities and class relationships[20]. The three diagrams explain the four use cases in the use case diagram, which are: choosing a product, QR code scan, database, and payment. There are four activity diagrams and four sequence diagrams that consist of selecting products, QR code scan, database, and payment.

All UML components used in this activity have dependencies and interrelationships in the process of describing their business models, which are following the rules of objectoriented system modelling [12]. The following is one of the activity diagrams and sequence diagrams contained in this study. Both diagrams explain the use of QR code scan cases. Starting from the QR code scan activity diagram, which has one actor, namely the customer, the activity carried out by the customer is doing a QR code scan on the product tag to get product information. Then proceed with a sequence of QR code scan diagrams that have three actors, namely customer, application, and product. A series starts from the customer opening the application and then ends with the product information displayed in the application; the diagrams can be seen in Figure 8 and Figure 9. 
INTENSIF, Vol.4 No.2 August 2020

ISSN: 2580-409X (Print) / 2549-6824 (Online)

DOI: https://doi.org/10.29407/intensif.v4i2.14097

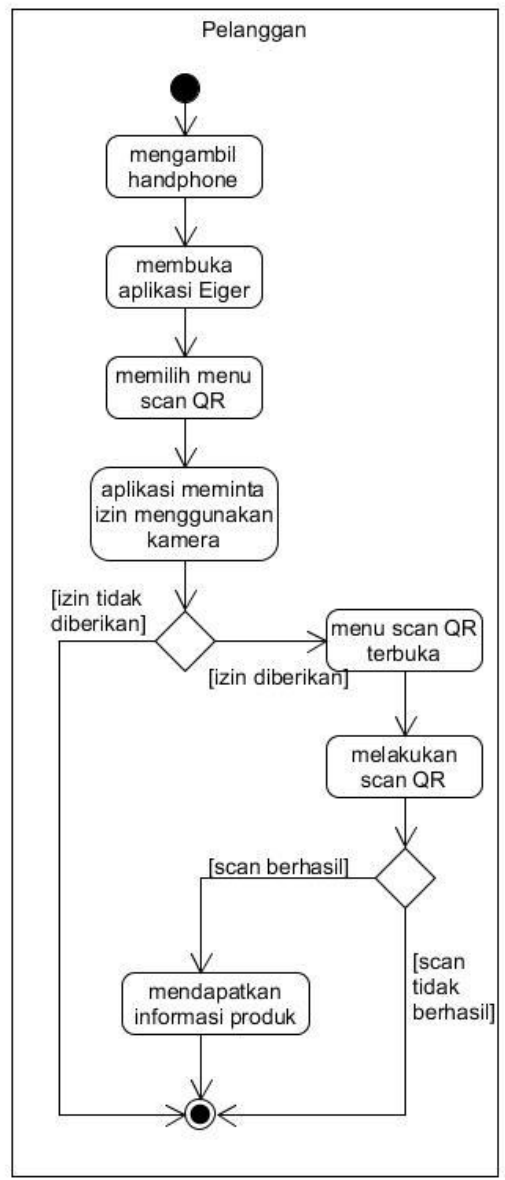

Figure 8. ACTIVITY DIAGRAM PROCESS QR CODE SCAN

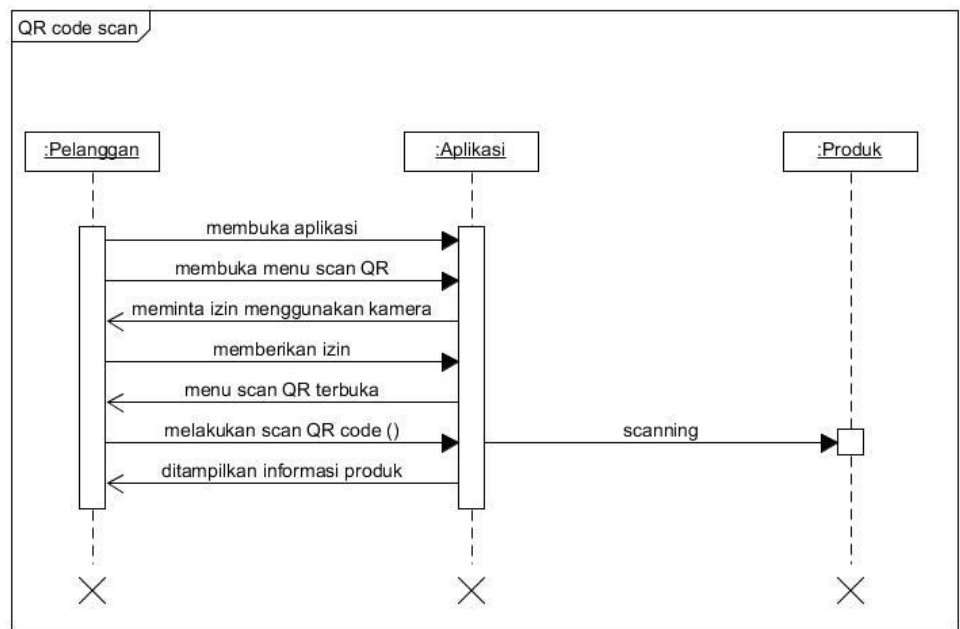

Figure 9. SEQUENCE DIAGRAM PROCESS QR CODE SCAN

c. Class Diagram QR code scan

Class Diagrams show descriptions of dependencies between classes and their relationships, which are designed based on use case diagrams and sequence diagrams 
INTENSIF Vol.4 No.2 August 2020

ISSN: 2580-409X (Print) / 2549-6824 (Online)

DOI: https://doi.org/10.29407/intensif.v4i2.14097

[12]. Class diagrams in UML are used to obtain information about the system to be developed, as well as data management processes that occur in the business model [12][21]. In this section, there are five main classes, namely: customers, cashiers, warehouse employees, employees, and admins. The following is a class diagram of Eiger Adventure Store Bandung based on use case diagrams and sequence diagrams. This diagram explains the relationship between classes and subclasses, which can be seen in Figure 10.

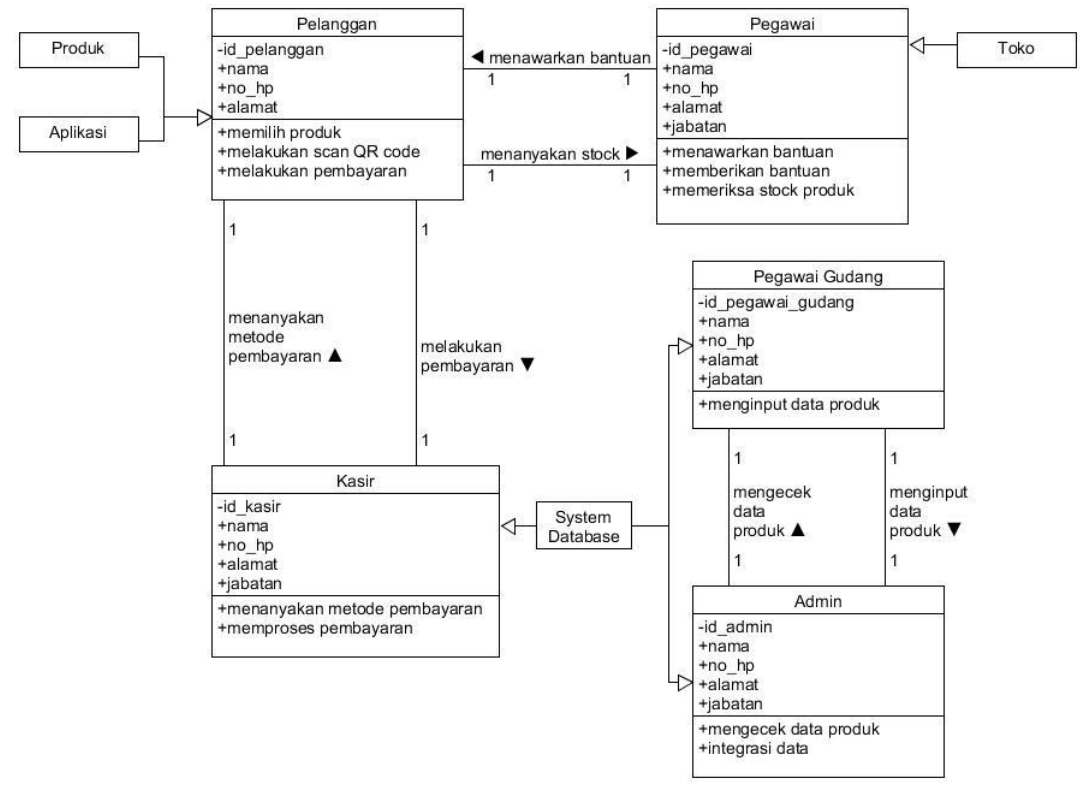

Figure 10. Class Diagram Eiger AdVENTURE StORE BANDUNG

\section{Mockup User Interface Design}

Mapping out the mockup design contained in the recommendations of this model, a menu structure is then presented that shows the interrelationships between the business models designed. The mockup user interface design show the QR Scan business model that has interdependent and interrelated subprocesses. These are Request Access, QR Scan, and Product Information. In Figure 11, a display structure of the mockup menu that has been designed for this research recommendation.

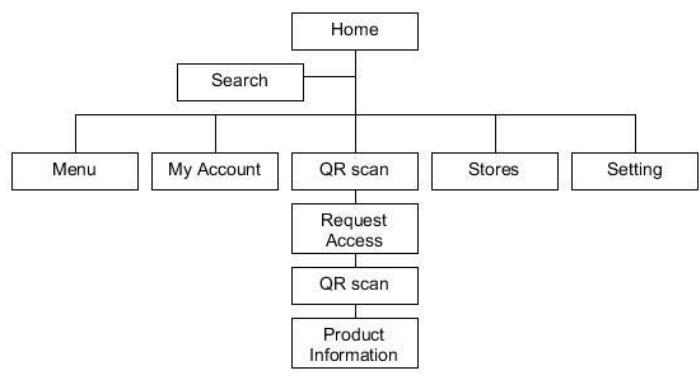

Figure 11. MENU STRUCTURE OF MOCK UP USER INTERFACE 
There are three mockup user interfaces. Mockup, the user, interface consists of home, request access and QR code scan, and product information. The following is one mockup of the user interface. On the results of the mockup user interface, it can be observed that the QR code scan is used as a reference in checking product authenticity. In this business model, the application can be downloaded from the Eiger Web so that when purchasing a product, the customer can immediately check the authenticity of the product. Please see Figure 12.

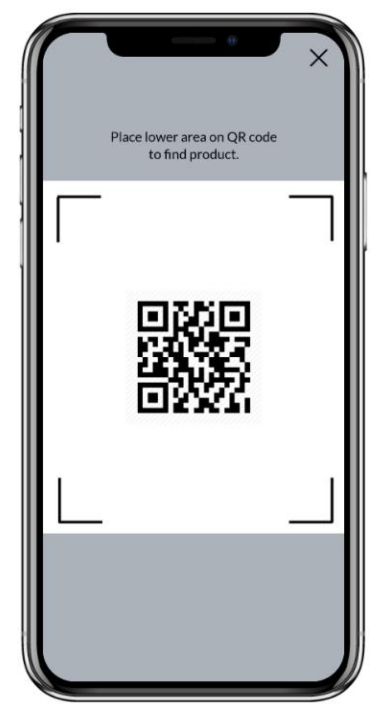

Figure 12. MOCK-UP USER INTERFACE QR CODE SCAN

D. Validity Test

Qualitative research requires testing the validity of data through a credibility test, a transferability test, a dependability test, and a confirmability test. [22]. Here is the result of qualitative research data validity test conducted in this study, namely:

1. Credibility Test

This study uses selected speakers to represent Eiger Adventure Store Bandung as a credibility test. The following are references to the credibility of sources, as presented in Table 2.

Table 2. INTERVIEWEE TABLE

\begin{tabular}{|c|c|}
\hline INTERVIEWEE & The Role of Interviewees \\
\hline Store Manager & $\begin{array}{l}\text { - As the owner of the highest position at } \\
\text { Eiger Adventure Store Bandung JL. } \\
\text { Sumatra No.23, Bandung, West Java } \\
\text { - Know all the business models in the store } \\
\text { - Have full responsibility for all activities in } \\
\text { the store }\end{array}$ \\
\hline
\end{tabular}


INTENSIF Vol.4 No.2 August 2020

ISSN: 2580-409X (Print) / 2549-6824 (Online)

DOI: https://doi.org/10.29407/intensif.v4i2.14097

This research also extends observations, uses reference material, and holds member checks. The extension of observation is carried out to test the credibility of the research data; the results of the extension of the study are an extension of the observation addressed to the store manager. Then use reference material in the form of interviews and also conduct a member check, which is evidenced by the data provider signature on the interview result sheet.

2. Transferability Test

This study does not aim to apply the results of the resource persons (samples) to the population (all Eiger Adventure Store companies in Indonesia) because it focuses on the Eiger Adventure Store in Bandung. Therefore the research does not conduct a transferability test and does not guarantee this external validity.

3. Dependability Test

In this testing activity, it is carried out directly at the location of the object by the interview process in the field, to obtain reliable data validity. Based on the results of the interview, Eiger Adventure Store Bandung, and the auditor (supervisor) stated that there was reliability through interview statements regarding the dependence of all research activities. For example, in the statement between the Eiger with the customer and between the supplier with the production.

4. Comfirmability Test

The process of confirmability testing is similar to dependability testing. In this case, testing and conclusions can be done simultaneously at the time of the dependability process. The results of this test can be examined based on interview statements that have been approved by the Eiger Adventure Store Bandung and the auditor (research supervisor)

\section{CONCLUSION}

Based on the results of the study, it can be concluded that, by knowing the business model that is happening to Eiger, it can be obtained a business model canvas recommendation based on a SWOT analysis. Referring to the business model canvas results of this study, then a new business model recommendation can be given, namely a QR code scan. This business model has been described with a unified modeling language (UML) and is visualized with a mockup user interface. The UML diagram involved is a use case diagram consisting of five actors, namely customers, employees, cashiers, admins, and warehouse employees. The actor interacts in four 
use cases, namely choosing a product, QR code scan, database, and payment. Likewise, for use case scenarios, activity and sequence diagrams consist of four interdependent and interrelated circuits in the process. The class diagram consists of five main classes, namely: customers, employees, cashiers, admins, and warehouse employees. Besides, some sub-classes have a dependency on the process, namely: products, applications, stores, and database systems. QR code scan provides education to customers to be able to distinguish genuine and fake products. Experts agree that providing education to customers can enable customers to identify counterfeit goods, stop imitations that are illegally produced, and make ethical and honest purchasing decisions. Suggestions given from the results of this study, namely Eiger Adventure Store Bandung, can apply the business model to overcome problems related to imitation products.

\section{ACKNOWLEDGMENTS}

This research is supported by the Telecommunications and Information Business Management Study Program (MBTI) and the Software Engineering Study Program (RPL) at Telkom University, as a place to explore data and complete the preparation of research reports. Besides, the authors also thank Eiger Adventure Store Bandung, which has deigned to be the object of this research.

\section{REFERENCES}

[1] Badan Ekonomi Kreatif, "Data Statistik dan Hasil Survei," Has. Survei Khusus Ekon. Kreat., p. 23, 2018.

[2] Kementerian Perindustrian, "Indonesia Punya Basis SDM Kembangkan Ekonomi Kreatif," $2014 . \quad$ [Online]. Available: http://www.kemenperin.go.id/artikel/8864/Indonesia-Punya-Basis-\%09\%09SDMKembangkan-Ekonomi-Kreatif.

[3] R. P. Pratama and E. Aziz, "Analisis Model Bisnis dengan Pendekatan Business Model Canvas (Studi Kasus MxD)," e-Proceeding Manag., vol. 5, pp. 3005-3019, 2018.

[4] A. Osterwalder and Y. Pigneur, Business Model Generation. Jakarta: PT Elex Media Komputindo, 2012.

[5] R. Rundupandang and Y. Priyadi, "Perancangan UML Sebagai Rekomendasi Proses Bisnis Berdasarkan BMC Di Geoff Max Bandung," J. Wacana Ekon., vol. 18, no. 1, pp. 13-21, 2018.

[6] A. Nur et al., "Comparison of Business Model Canvas (BMC) Among the Three Consulting Companies," ISSN Int. J. Comput. Sci. Inf. Technol. Res. ISSN, vol. 3, no. 2, pp. 2348-1196, 2015.

[7] B. Abdeldjebbar and B. Azeddine, "Generating interface prototype for EnergyPlus IDD file using unified modeling language and coloured petri-nets," Energy Procedia, vol. 18, pp. 1458-1484, 2012, doi: 10.1016/j.egypro.2012.05.164.

[8] D. Torre, Y. Labiche, M. Genero, M. T. Baldassarre, and M. Elaasar, "UML diagram synthesis techniques: A systematic mapping study,” Proc. - Int. Conf. Softw. Eng., no. August, pp. 33-40, 2018, doi: 10.1145/3193954.3193957.

[9] M. Ibrar, "UML Diagrams : an Aid to Database Design Specification : A Review," Int. J. 
INTENSIF Vol.4 No.2 August 2020

ISSN: 2580-409X (Print) / 2549-6824 (Online)

DOI: https://doi.org/10.29407/intensif.v4i2.14097

Adv. Res. Comput. Sci. Softw. Eng., vol. 3, no. 3, pp. 598-602, 2013.

[10] S. Uke and R. Thool, "UML Based Modeling for Data Aggregation in Secured Wireless Sensor Network," Phys. Procedia, vol. 78, no. December 2015, pp. 706-713, 2016, doi: 10.1016/j.procs.2016.02.120.

[11] I. L. H. Alsammak, "A methods of ensuring consistency between UML Diagrams," J. Univ. Kerbala, vol. 16, no. April, pp. 407-417, 2018.

[12] R. Sukmawati and Y. Priyadi, "Perancangan Proses Bisnis Menggunakan UML Berdasarkan Fit/Gap Analysis Pada Modul Inventory Odoo," intensif, vol. 3, no. 2, pp. 104-115, 2019.

[13] M. R. Roth, A. Dennis, and B. H. Wixom, System Analysis and Design (5th Edition). Singapore: John Wiley \& Sons Singapore, 2013.

[14] Y. Priyadi and A. Prasetio, "Implementation of Supply Chain Business Application through Business Model Canvas and Waterfall Framework Collaborations for Fish Farmers SMEs in Ulekan Market Bandung."

[15] Y. Priyadi and J. Hatammimi, "Development of e-SCM Open Source as Integration of Data Management For Fish Farmers SMEs in Pasar Ulekan Bandung."

[16] P. Kotler and K. L. Keller, Marketing Management (14th Edition). Harlow: Pearson Education, 2012.

[17] E. GÜREL, "SWOT Analysis: A Theorical Review," J. Int. Soc. Res., vol. 10, no. 51, pp. 994-1006, Aug. 2017, doi: 10.17719/jisr.2017.1832.

[18] M. Touseef, N. Anwer, A. Hussain, and A. Nadeem, "Testing from UML Design using Activity Diagram: A Comparison of Techniques," Int. J. Comput. Appl., vol. 131, no. 5, pp. 41-47, 2015, doi: 10.5120/ijca2015907354.

[19] N. I. Yusman, "Perancangan Sistem Informasi Berbasis Orientasi Objek Menggunakan Star UML di CV Niasa Bandung," AIMS J. Account. Inf. Syst., vol. 1, no. 2, pp. 1-9, Sep. 2018, doi: 10.32627/aims.v1i2.18.

[20] K. E. Kendall and J. E. Kendall, Systems Analysis and Design (9th Edition). Harlow: Pearson Education, 2014.

[21] F. Alhumaidan, "A Critical Analysis and Treatment of Important UML Diagrams Enhancing Modeling Power," Intell. Inf. Manag., vol. 04, no. 05, pp. 231-237, 2012, doi: 10.4236/iim.2012.45034.

[22] Sugiarto, Metodologi Penelitian Bisnis. Yogyakarta: Penerbit Andi, 2017.

202 INTENSIF: Jurnal Ilmiah Penelitian dan Penerapan Teknologi Sistem Informasi 